УДК $811.163 .4^{\prime} 366.543$

$811.14^{\prime} 02^{\prime} 366.543$

https://doi.org/10.18485/primling.2016.17.2

\title{
Панајотис Асимопулос
}

Војна Академија Грчке

\section{СТАРОГРЧКИ ГЕНИТИВ И (СРПСКО)ХРВАТСКИ ПРЕВОДНИ ЕКВИВАЛЕНТИ ИЗ ПСЕУДО-ЛОНГИНОВОГ ЕСЕЈА «О УЗВИШЕНОМ» ${ }^{1}$}

\begin{abstract}
Сажетак: Служећи се беспредлошким генитивним синтагмама као заједничким именитељем, овај рад представља пионирски покушај да на синтаксичком нивоу упореди два индоевропска језика, односно, изумрли старогрчки и савремени (српско)хрватски. Како бисмо указали на сличности и разлике у употреби генитива у обама језицима, вршили смо теоријско испитивање његових основних принципа, на примерима из античких текстова (Платон, Херодот, Тукидид). Поредбени корпус узели смо из оригиналног текста, из Псеудо-Лонгиновог есеја „О узвишеном“. Тај корпус чини 463 примера на старогрчком језику, чији се преводни еквиваленти на (српско)хрватском установљују на основу превода Тона Смердела.
\end{abstract}

Кључне речи: Псеудо-Лонгин, генитив, старогрчки, (српско)хрватски.

\section{1. Уводна разматрања}

Упркос доминантној тенденцији према којој се истраживачи првенствено осврћу на морфосинтаксичке и лексичкосемантичке параметре савремених народних језика, историјско-компаративни приступ феноменима старогрчког разложно заслужује диахроно интересовање лингвиста и синтаксичара.

Предмет рада јесте контрастивно истраживање беспредлошких генитивних структура у старогрчком и модерном (српско)хрватском језику. Као методолошки оквир примењена је метода контрастивне анализе, односно, структурносемантичког поређења, док је синхрони приступ поређењу заснован на корпусној обради ексцерпиране грађе.

Четиристо шездесет три примера преузето је из оригиналног Псеудо-Лонги-

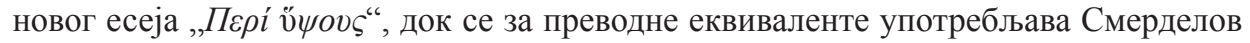
превод „О узвииеном“.

1 Искрено се захваљујем професору књижевности и песнику Дејану Ђорђевићу за корисне сугестије и суштинску подршку око лекторисања рада. 


\section{2. Основна обележја старогрчког генитива}

Не усвојивши читаво падежно устројство индоевропске матрице старогрчки има пет саставних делова: номинатив, генитив, датив, акузатив и вокатив. Значи, да су главне функције аблатива, инструментала и локатива ограничене само у адвербијалним манифестацијама и изражене осталим падежним структурама.

Генитив са именицама и придевима указује на спој или зависност чију идентификацију илуструју: (а) контекстуални оквир; (б) семасиолошке нијансе; (в) чињенице које се сматрају познатим (Smyth 1920: 313). Разликује се на (1) аблативни генитив; (2) апозитивни генитив; (3) генитив вредности (цене); (4) генитив материје; (5) генитив ствараоца (проистицања - узрочника); (6) каузативни (узрочни) генитив; (7) квалификативни генитив; (8) квантитативни генитив; (9) објекатски генитив; (10) партитивни (деони) генитив; (11) поредбени (компаративни) генитив; (12) посесивни (присвојни) генитив; (13) субјекатски генитив:

\section{1. Аблативни генитив (Genetivus ablativus)}

Према Дукату (1983: 229-230), старогрчки генитив често означава функције аблатива, а конкретније, полазну тачку. Удружује се уз:

(a) географске ознаке:

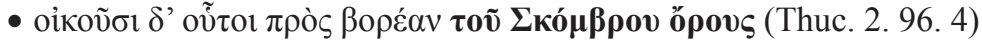

$>$ они живе северно оg йланине Скомбра

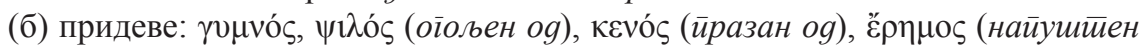

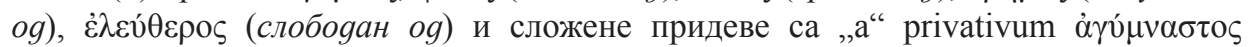

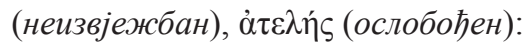

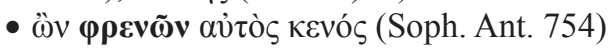

$>\quad$ пошто је сам празан оg йамейи

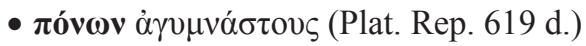

$>$ неизвежбане у найорима

\section{2. Апозитивни генитив (Genetivus appositivus / epexegeticus)}

Генитив експлицитне речи разјашњава појам неке опште речи која није изражена у том падежу. Јавља се са ентитетима који означавају порекло, материју, и

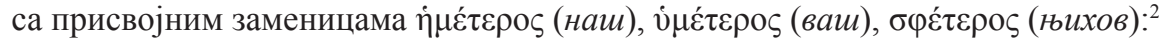

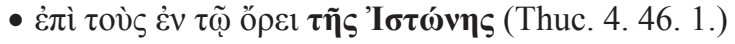

$>$ против оних на планини Истионе

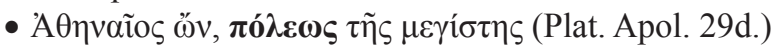

$>$ пошто си Атињанин, то јест, из великог ірpaga

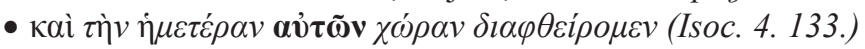

$>$ и своју земљу уништавамо

\section{3. Генитив вредности или цене (Genetivus pretii)}

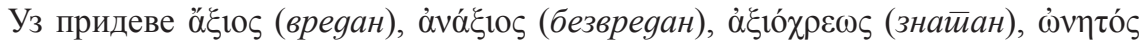

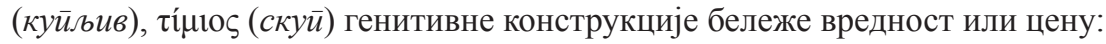

2 M $2 \hat{\imath} \lambda \lambda \alpha$ 2010: 26 


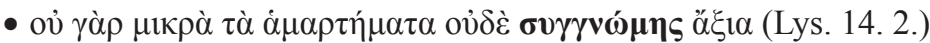

$>$ зато што његови прекршаји нису мали, нити су заслужни вашег ирашйањ $a$.

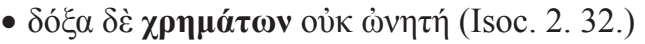

$>$ слава није купљива новцеем

\section{4. Генитив материје (Genetivus materiae)} 1966: 22)

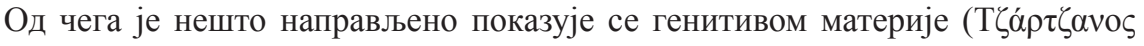

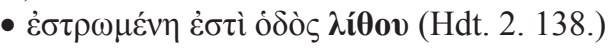

$>$ Камењем поплочана цеста

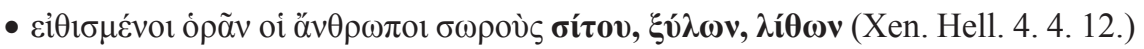

$>$ људи су навикнути да виде гомиле жийа, йалица, камена

2.5. Генитив ствараоца (проистицања / узрочника) (Genetivus auctoris)

Лице или персонификован беживотни ентитет у генитиву показује ствараоца интелектуалног дела:

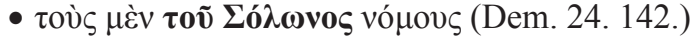

$>$ законе Солона

\section{6. Каузативни (Узрочни) генитив (Genetivus causalis)}

Овај тип генитива открива узрок и обично зависи од именица и придева

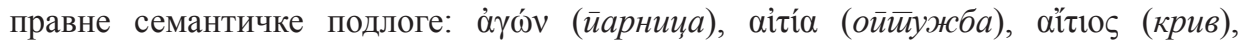

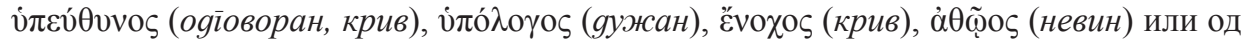

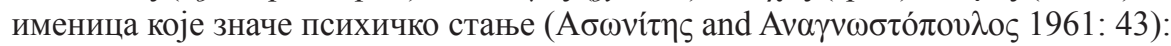

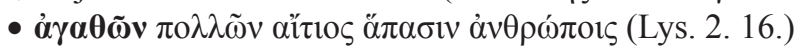

$>\quad$ он је разлог многих яоброчинстиава према свим људима

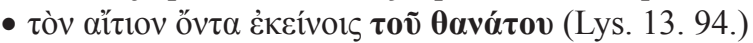

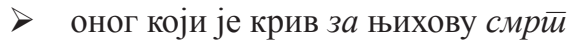

\section{7. Квалификативни генитив (Genetivus qualitatis)}

Карактеристично својство (величина, узраст, димензија, мера) презентује се бројевима и квалификативним генитивом:

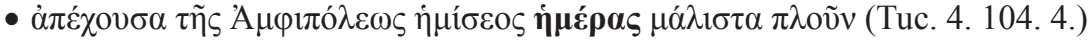

$>$ удаљен је од Амфиполиса највише пола gана путовања бродом

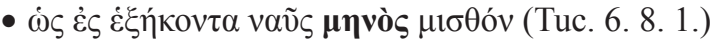

$>$ отприлике, месечна награда за посаду шездесет бродова

\section{8. Квантитативни генитив (Genetivus quantitatis)}

Тај генитив ${ }^{3}$ показује садржај објекта или појма који значи мноштво или

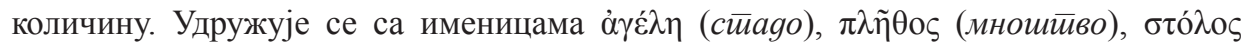

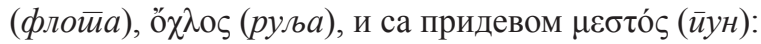

- $\boldsymbol{\beta o \tilde { \omega } \mathbf { v } \alpha \dot { \gamma } \varepsilon ́ \lambda \eta \varsigma ~ v o \mu \varepsilon v ́ \varsigma ~ ( X e n . ~ A p o l . ~ 1 . ~ 2 . ~ 3 2 . ) ~}$

$>$ пастир стада волова

3 Сабалевски (2000: 268) је назива genetivus generis. 
- $\tau$ ò $\pi \lambda \tilde{\eta} \theta 0 \varsigma \boldsymbol{\tau} \tilde{\boldsymbol{\omega}} \mathbf{v} \mathbf{v \varepsilon \tilde { \boldsymbol { \omega } } \mathbf { v }}$ (Xen. Hell. 1. 1. 15.)

$>$ мноштво бродова

\section{9. Објекатски генитив (Genetivus obiectivus)}

Објекатски генитив бележи предмет радње коју казује глаголска именица. Он се удружује са истокоренским именицама или придевима глагола који прихватају директан објекат у генитиву, а значе: (а) памћење, заборав; ${ }^{4}$ (б) бригу, марљивост, штедљивост; (в) учешће, пуноћу, лишавање; (г) раздвајање, уклањање, ослобађање; (д) иксуство, незнање, успех, неуспех; (ђ) власт, потчињење; (е) разлику, поређење:

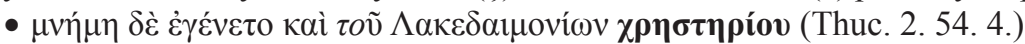

$>$ сетили су се и йророчансиива које су узели од Спартанаца

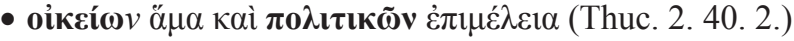

$>$ истовремена брига о сойстивеним и државним аферама

- $\tau \tilde{\boldsymbol{\omega}} \mathbf{v} \dot{\varepsilon} \pi \imath \tau \eta \delta \varepsilon \dot{\omega} \omega \mathbf{v} \dot{\varepsilon} v \delta \varepsilon \varepsilon i \tilde{\varsigma}$ (Lys. 13. 11.)

$>$ лишени неойхоgних сйвари

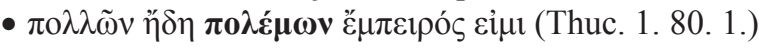

$>$ већ имам искуство од многих райова

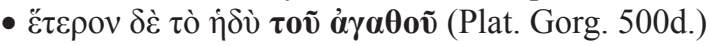

$>$ задовољство разликује се $o g$ gоброї

Сходно томе објекатски генитив личних заменица је еквивалентан присвојним заменицама (Musić i Majnarić 1980 $\left.{ }^{11}: 184\right)$ ):

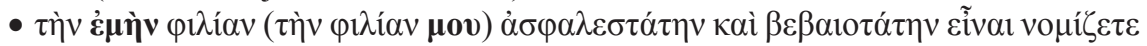
(Isoc. 3. 54.)

$>\quad$ верујете да је моје пријатељство (ми је пријатељство) сигурно и трајно

\subsection{0. Партитивни (Деони) генитив (Genetivus partitivus)}

Увек има предикатан положај (Мусић и Мајнарић $1980^{11}$ : 185) и показује део целине, углавном са речима које значе количину. Genetivus quantitatis (Сабалевски 2000: 267) следе бројеви или именичке заменице:

- oi $\pi$ o $\lambda \lambda$ oì $\tau \tilde{\boldsymbol{\omega}} \boldsymbol{v} \boldsymbol{\sigma} \boldsymbol{\tau} \boldsymbol{\alpha} \boldsymbol{\alpha} \boldsymbol{\tau} \boldsymbol{\omega} \boldsymbol{\tau} \tilde{\boldsymbol{\omega}} \mathbf{v}$ (Xen. Hell. 4. 2. 5.)

$>$ многи оg војника

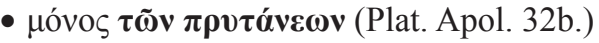

$>$ сам оg ирийана

- $\tilde{\varepsilon} v \dot{\varepsilon} \theta \alpha v ́ \mu \alpha \sigma \alpha \tau \tilde{\boldsymbol{\omega}} \mathbf{v} \boldsymbol{\pi} \boldsymbol{0} \lambda \lambda \tilde{\boldsymbol{\omega}} \mathbf{v}$ (Plat. Apol. 17a.)

$>$ зачудио сам се једном оg мнойих

Веома је чест са топонимима ${ }^{6}$, поименичним придевским и заменичким облицима средњег рода, или са суперлативом придева:

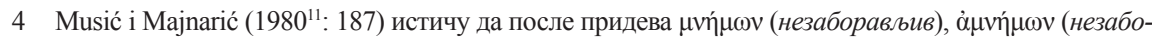

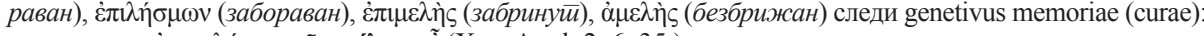

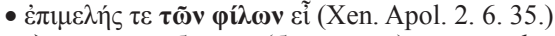
$>$ ти си забринут (бринеш се) za prijatelje

5 Musić i Majnarić (1980 11 : 188) као genetivus potentiae карактеришу генитив који се удружује са

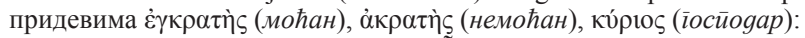

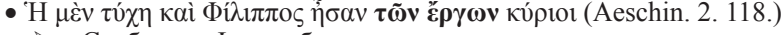

$>$ Судбина и Филип били су господари gела.

6 Ради се о хороїрафијском їенийиву (Smyth 1920: 316) 


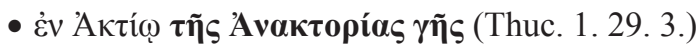

$>\quad$ на Актијуму из земље Анакйорије

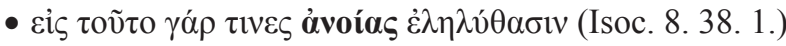

$>$ дотле неки су дотерали у махнииостии

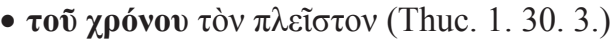

$>$ највише (најдуже) времена

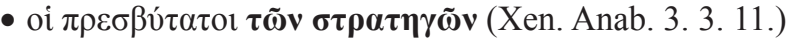

$>$ најстарији оg војсковођа

\subsection{1. Поредбени (Компаративни) генитив (Genetivus comparationis)}

Јавља се са придевима у компаративу или са оним који бележе поређење

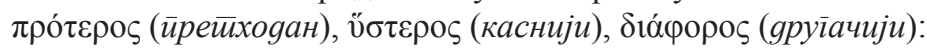

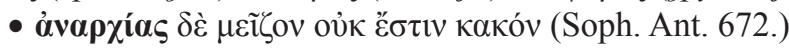

$>$ og нейослуха нема ти већег зла

\subsection{2. Посесивни (присвојни) генитив (Genetivus possessivus)}

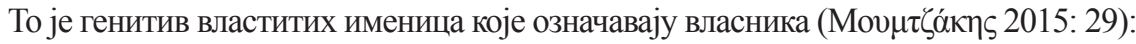

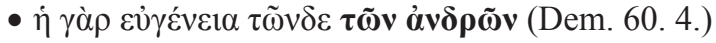

$>$ племенитост тих мушкарациа

Међутим, и родбински односи изражавају се тим генитивом, најчешће са

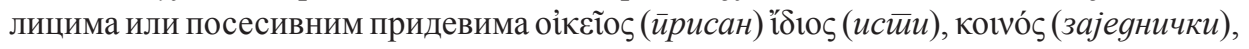

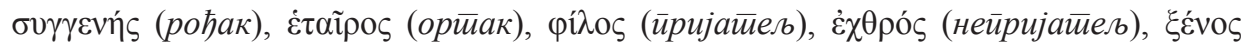
(стиранаи):

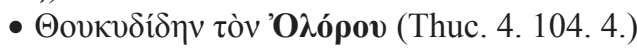

$>$ Тукидида, сина Олора

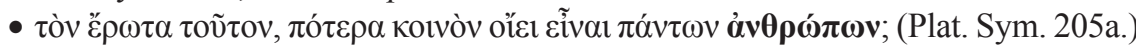

$>$ ову љубав сматраш да је заједничка код свих љљgu?

Како Smyth (1920: 314) наглашава успешно члан средњег рода (у једнини или множини) са посесивним генитивом означава моћ, околности или функционише као права перифраза:

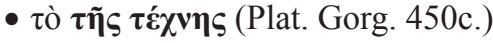

$>$ функција уметиносиии

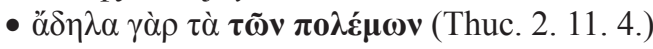

$>$ нејасне су прилике райова

Поткатегоријом посесивног генитива Сабалевски (2000: 266) сматра їенийив карактиеризујућей својсиива (genetivus characteristicus). Уз инфинитив изражава лице на које се односи радња или стање:

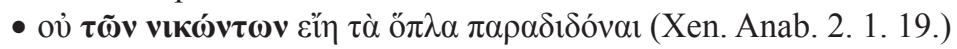

$>$ йобеgнищима није својство да предају своје оружје

\subsection{3. Субјекатски генитив (Genetivus subiectivus)}

Именичка реч која субјекатским генитивом означава вршиоца радње, обично је глаголска именица ,или носи глаголско значење:

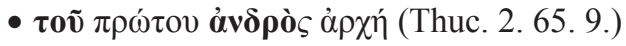

$>$ власт најспособнијег мушкариа 


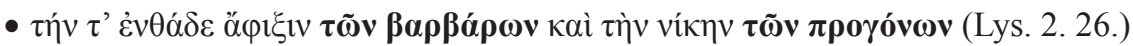

$>$ овдашњи долазак варвара и победу наших йреgака

Субјекатски генитив има активан појам, док објекатски пасиван (Smyth 1920: 319):

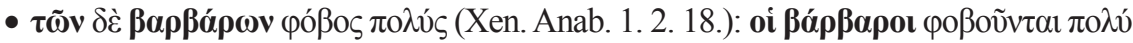

$>$ велики је страх варвара: варвари плаше се много

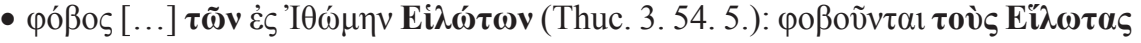

$>$ страх [...] од Хелота у Итоми: плаше се Хелой

\section{3. Осврт на (српско)хрватске преводне еквиваленте}

За прегледно проучавање употребе беспредлошких генитивних структура сматрамо да је неопходно да се осврнемо на теоретска обележја преводних еквивалената адноминалним генитивним структурама у (српско)хрватском језику.

Затим, на основу одабраних примера из Псеудо-Лонгиновог есеја „О узвишеном“ и Смерделовог преводилачког приступа, и то ради конструктивне анализе следи паралелно излагање испитаних структура у оба језика.

У грчком језику уобичајена је подела на десет категорија беспредлошких генитива који стоје уз именице или придеве. То су: (1) вредности или цене; (2) квалитативни; (3) квантитативни; (4) објекатски; (5) партитивни (деони); (6) поредбени (компаративни); (7) присвојни (посесивни); (8) ствараоца; (9) субјекатски; (10) узрочни (каузални).

С друге стране у својству (српско)хрватских преводних еквивалената јавља се осам подкласа генитива: (1) аблативни; (2) квалитативни; (3) компаративни (поредбени); (4) објекатски; (5) партитивни (деони); (6) присвојни (посесивни); (7) субјекатски; (8) узрочни (каузални), али и: (9) квалитативни инструментал; (10) описни придев; (11) присвојна заменица; (12) присвојни датив; (13) присвојни придев.

\section{1. Аблативни генитив: $\mathrm{V}+\operatorname{Det}_{\mathrm{Abl}}\left[\leftarrow \mathrm{N}_{\mathrm{Gen}}\right]^{7}$}

Реченични додатак аблативног генитива односи се на именице изведене од глагола који понекад имају рефлексивни (повратни) облик. Најчешће означавају (1) удаљавање, лишавање, одвајање; (2) избор, порекло; (3) потицање (Пипер и др. 2005: 137):

$>$ чување болесии $u<$ чувати се болести

$>$ ослобађање стираха < ослобађати се страха

К томе Мразовић и Вукадиновић (1990: 293) истичу да се у генитивним синтагмама аблативни генитив замењује од предлошком конструкцијом (предлог $o g+$ генитив):

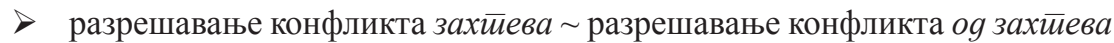

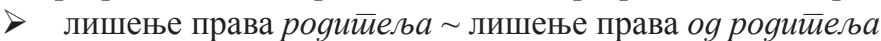

(Српско)хрватски еквиваленти изражени аблативним генитивом јављају се у формама (a) квантитативног; (b) партитивног; (c) поредбеног генитива, и то помоћу предлошких структура:

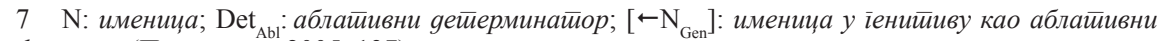
ияенииификайор (Пипер и др. 2005: 137) 
* 《 $\quad\langle o g+\bar{\imath} е н и \bar{u} и в »:$ то је допуна прелазном глаголу који се удружује са акузативом у својству правог објекта;

* «из + іениииив»: на однос припадности у позицији именског дела предиката указује та предлошка конструкција (Фелешко 1995²: 90):

(a) квантитативни генитив

(i) од + генитив

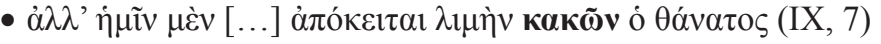

$>$ смрт као лука која нас спасава og зала (стр. 18)

(б) партитивни (деони) генитив

(i) из + генитив

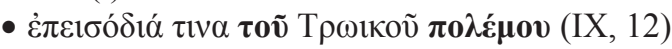

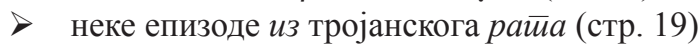

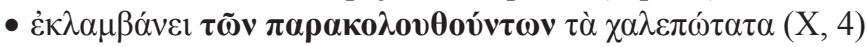

$>$ изабире из случајне околносии и оне најпотресније (стр. 22)

(ii) од + генитив

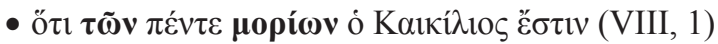

$>\quad$ да је Цецилије og иеей сйоменуииих gијелова (стр. 15)

(в) поредбени генитив

(i) од + генитив

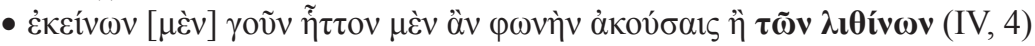

$>$ прије би могао чути коју ријеч од мраморних кипова неголи og њих (стр. 11)

\section{2. Квалитативни генитив: $\mathrm{N}+\operatorname{Det}_{\text {Qual }}\left[\leftarrow \mathrm{N}_{\text {Gen }}\right]^{8}$}

Усклађен са аутентично атрибутском детерминацијом генитив својства удружује се обавезно са именицом која „није сама, него је дружена с којом покретном речи“ (Маретић $1963^{3}: 572$ ). Поменуту карактеристику налазимо и код Милке Ивић (1959: 152): „За квалитативни генитив је такође познато да се обавезно јавља у конструкцији са одредбом““.

Такве именице конкуришу придевима или придевским партиципима у функционалној улози квалификативних детерминатора, а одражавају апстрактне појмове са интегралном значењском подлогом живих ентитета (делови тела, психофизичка обележја) или предмета:

$>$ Свидела му се она девојка плавих очију и ведра осмеха. (Симић 2002: 177)

Додајмо, да се ти генитиви замењују описним придевима, под условом ,да се идентитет њиховог садржаја не поистовећује семасиолошки (Ивић 1955 - 1956: 264):

$>$ Понекад је излазила са старијом женом стироїа и нейријайна израза лица.

Преводни еквиваленти генитивним конструкцијама чија је синтаксичка улога адноминални квалификатор остварују се помоћу (а) квалитативних; (б) објекатских; (в) партитивних генитива:

(а) квалитативни генитив 
Слободним генитивом одражава се одлика на суперлативном нивоу:

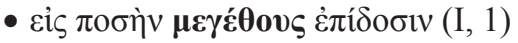

$>$ на неку вишу разину стиила (стр. 5)

(б) објекатски генитив

Номинализовани облик глагола идентификује се са акузативном допуном, тј. правим објектом:

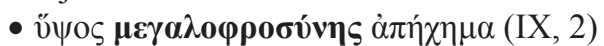

$>$ узвишено је одјек великоїа gуха (стр. 16) одјек < одјековати

(в) партитивни (деони) генитив

Уз квантификативне именице генитив бележи целину из које издвајамо део:

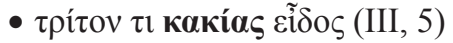

$>$ трећи вид искварена стила (стр. 9)

\section{3. Квалитативни инструментал: $\mathrm{V}+\operatorname{Det}_{\text {Qual }}\left[\leftarrow \mathrm{N}_{\text {Instr }}\right]^{9}$}

Двојаку синтаксичку функцију манифестује квалитативни инструментал, односно, придевски идентитет (наглашава се стално обележје, док је замењив генитивом, само ако је именица праћена атрибутом), и прилошку улогу (привременост карактерише инструменталне конструкције).

Иначе, према Милки Ивић (1954: 204) квалитативни инструментал „Употребљава се у свим случајевима без обзира какав је појам у питању, само ако се ради о примерима који по својој семантичкој структури спадају у категорију «карактеристичне појединости»".

У (српско)хрватском преводу квалитативни инструментал је везан само за објекатски генитив старогрчког оригинала:

(а) објекатски генитив

Ивић (1954: 67) пасивним инструменталним конструкцијама приписује функцију спроводника вршења или изазивача стања:

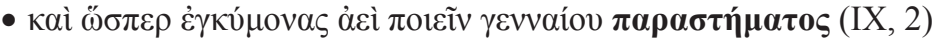

$>$ да буду испуњене племенитим осјећањима (стр. 16)

3.4. Компаративни генитив: $\mathbf{N}+\mathrm{Cop}+\operatorname{Adj}_{\mathrm{Komp}}+\mathbf{N}_{\mathrm{Gen}}{ }^{10}$

За успостављање односа једнакости или различитости између два ентитета, генитивне конструкције отелотворују се придевима у компаративу.

Грчком независном генитиву који обележава поређење еквивалентне су предлошке конструкције:

* 《између + іенийив»: упркос томе, што првобитно одређује просторне димензије, често изражава и компаративне нијансе

* «међу + инсиируменйал»: осим месних параметара на непрецизан начин означава личне и диференциране одлике

* 《og + іенийив»: те формације „се лоцирају у именском делу предиката или су побочне предикативне одредбе“ (Фелешко 1995²: 112)

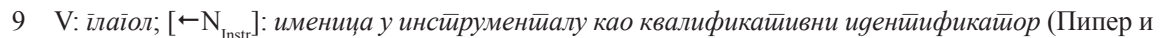
др. 2005: 256)

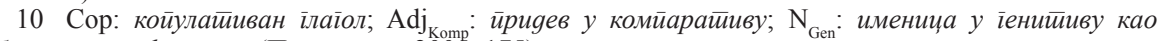
йореgбени ияенииификайор (Пипер и др. 2005: 175) 
(a) поредбени генитив

(i) између + генитив

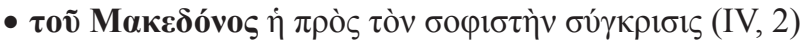

$>$ та успоредба између Макеgонаца и софиста (стр. 10)

(ii) међу + инструментал

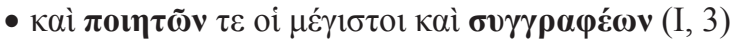

$>\quad$ те да су највећи међу йјеснищима и йрозаисйима (стр. 6)

(iii) од + генитив

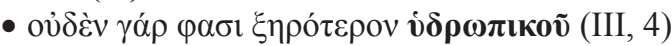

$>$ ништа није непријатније og човјека који болује og воgене болестии (стр. 9)

3.5. Објекатски генитив: $\mathrm{N}_{\text {Dev }}\left[<\mathrm{V}_{\text {tranz }}\right]+\operatorname{Obj}\left[\leftarrow \mathrm{N}_{\mathrm{Gen}}\right]^{11}$

Са девербативним именицама или именичким фразама које у значајној мери настају од несвршених (радња у процесу), или од свршених глагола (завршетак или резултат), независни генитив функционише као акузативна допуна (Мразовић Вукадиновић 1990: 289):

$>$ Народно йpegaње истиче да су виле биле добре супруге.

$>$ Двочасовно йреgавање о верској дискриминацији одушевило је студенте.

За примере који су у оригиналној верзији изражени генитивом вредности, објекатским и узрочним генитивом као преводни еквивалент употребљава се објекатски генитив:

(а) генитив вредности или цене

Придеви који означавају вредност или процену допуњавају синтаксички и семантички оквир објекатских структура у (српско)хрватском тексту:

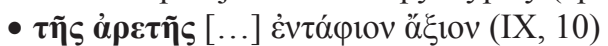

$>\quad$ погреб достојан храбростии (стр. 19)

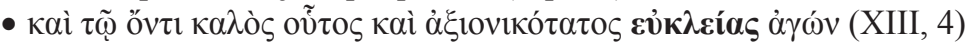

$>\quad$ такво је натјецање лијепо и заиста вриједно йобјеge (стр. 27)

(б) објекатски генитив

Позициона варијанта слободног акузатива у својству објекта је усклађена са именицама изведеним од транзитивних глагола:

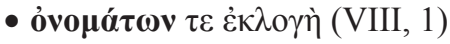

$>$ избор ријечи (стр. 14) избор < изабрати

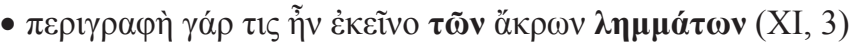

$>$ у описивању довршених мисли (стр. 24) описивање < описивати

(в) узрочни (каузални) генитив

Значењска идентификација каузалног генитива у грчком тексту постиже се објекатским еквивалентом у (српско)хрватском преводу:

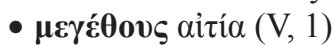

$>$ извор узвишеног̄ (стр. 14) избор < изабрати

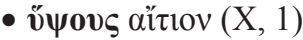

$>$ мотив узвишеної (стр. 21) мотив < мотивисати

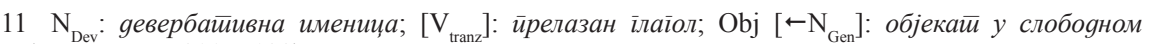
иенийиву (Пипер и др. 2005: 132) 


\section{6. Описни придев}

Одређена карактеристика и главно обележје која карактеришу мотивну именицу, бележе се помоћу придевских форми, тј. еквивалената квантитативном и објекатском генитиву.

Придеви са суфиском -ан који врше функцију преводног еквивалента указују на појам „имати оно што значи основна именица, обиловати тиме, бити од тога“ (Станојчић - Поповић $1999^{6}:$ 155):

(а) квантитативни генитив

- ő $\pi \lambda \omega v \mu v \rho t \alpha ́ \delta \varepsilon \varsigma$ (XLIII, 2)

$>$ езбројно оружје (стр. 63)

(б) објекатски генитив

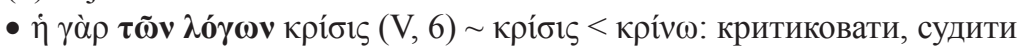
$>$ књижевна критика (стр. 13)

\section{7. Партитивни (деони) генитив: Quant ${ }_{\text {ParaNum }}+\mathrm{N}\left[\leftarrow \mathrm{N}_{\text {Gen }}\right]^{12}$}

Носећи семантички параметар квантификације „деони или партитивни генитив означава да се у датим околностима остварује само део садржаја именске речи“" (Симић 2002: 177):

$>\quad$ Набраћемо цвећа по ливади.

У српском корпусу као еквиваленти деоном генитиву јављају се облици квантитативног генитива. Према томе улогу паранумеричких квантификатора заузимају разломци или речи које не одређују прецизан број саставних делова:

(а) квантитативни генитив

Именица у номиналној синтагми испољава аспект количине; конкретније ту функцију врши генитив у улози детерминатора:

- $\tau \tilde{\omega} \pi \lambda \eta \dot{\theta \varepsilon \iota} \tau \tilde{\omega} \mathbf{v} \tau \rho о \pi \iota \kappa \tilde{\omega} \mathbf{v}(X X X I I, 2)$

$>$ мноштво метиафоричких израза (стр. 48)

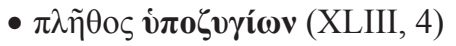

$>$ мноштво иееілеће марве

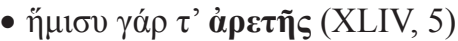

$>$ половину узме врлине (стр. 65)

\section{8. Присвојни (посесивни) генитив: $\mathbf{N}+$ Det $_{\text {Poses }}\left[\leftarrow \mathbf{N}_{\text {Gen }}\right]^{13}$}

Припадничка релација одређује се са посесивним детерминатором у својству атрибута и са именичким појмом.

(а) генитив ствараоца

Генитив личних имена која у грчким примерима указују на уметнике, књижевнике, изражава се посесивним генитивом:

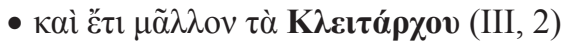

$>\quad$ још више изражаји лошег писца Клийарха (стр. 8)

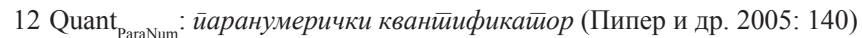

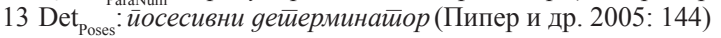


(б) објекатски генитив

Појам посесивности је замењив објекатским генитивом:

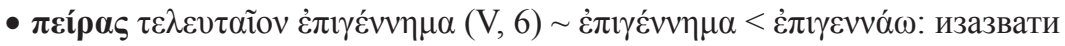
$>\quad$ плод дугог искустива (стр. 13)

(в) присвојни (посесивни) генитив

Интересантно је, да колико у (српско)хрватском, толико у грчком, именице које присвојним генитивом идентификују власника описаних појмова, појављују се у множини (Фелешко 1995²: 37):

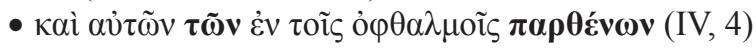

$>\quad$ очи самих gјевица (стр. 11)

- $\tau \rho \alpha v ́ \mu \alpha \tau \alpha \boldsymbol{\theta \varepsilon \tilde { \omega } \mathbf { v }}(\mathrm{IX}, 7)$

$>\quad$ о ранама боїова (стр. 18)

(г) $\mathbf{y}+$ генитив

Према Фелешку $\left(1995^{2}: 125\right)$ генитив са предлогом $y$ обележава истакнуту припадничку релацију и посесивни карактер:

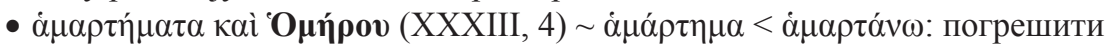
$>\quad$ недостатака $у$ Хомера (стр. 51)

\section{9. Присвојна (посесивна) заменица}

Прономинални облици којим се у (српско)хрватском преводу исказују посесивност, припадање живих и неживих ентитета лицима употребљавају се уместо личних прономиналних форми у грчком корпусу:

(а) присвојни (посесивни) генитив

У оба испитана језика подкатегорија присвојних генитива представља највећу учесталост. Еквивалентни облици присвојног генитива покривају значајан део (српско)хрватских примера:

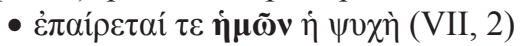

$>\quad$ нама се душа уздиже (стр. 13)

3.10. Присвојни (Посесивни) датив: $\mathbf{N}+$ Det $_{\text {Poses }}\left[\leftarrow \operatorname{ProN}_{\text {Dat }}\right]^{14}$

Енклитички облици личних заменица, иако нису реченични конституенти, понашају се као атрибути именицама са којим успостављају поседнички однос.

Уз то, према Мразовић-Вукадиновић (1990: 295) чест је у заклетвама (у 1. и 2. лицу једнине), али и у псовкама (у 2. и 3. лицу једнине - множине):

\section{$>\quad$ Живота ми!}

$>\quad$ Бога $\bar{u} u$ твога!

У (српско)хрватском преводу јавља се уз именице које значе део људског тела и кореспондира са грчким субјекатским генитивом:

(a) субјекатски генитив

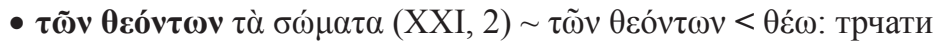
$>\quad$ удове ииркачима (стр. 38)

$14 \mathrm{ProN}_{\mathrm{Dat}}$ : лична заменийа y gaйиву (Пипер и др. 2005: 188) 


\subsection{1. Присвојни (посесивни) придев}

Морфолошки идентитет присвојних придева заснива се на именицама од којих су изведени, док је њихова семантичка разноврсност везана за припадност лицима (очев), предметима (ружин) или пореклу (беоїраgски).

Међутим „могу бити једнаки описним придевима, без обзира на термин којим се називају““ (Станојчић-Поповић 19996: 152):

храстиов лист: лист који припада храсту

храстиова столица: столица која је начињена од дрвета храста

(Српско)хрватски примери присвојног придева бивају означени облицима генитива ствараоца, присвојног генитива или посесивног придева:

(а) генитив ствараоца

Предмет стваралаштва је праћен генитивом који ојачава поседничку позадину:

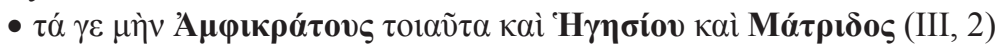

$>\quad$ такав је Амфикрайов, Хеїесијев и Майрияов стил (стр. 8)

(б) присвојни (посесивни) генитив

У грчком оригиналу бројне су конструкције чији је главни конституент присвојни генитив у својству преводног еквивалента:

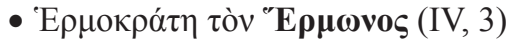

$>\quad$ Хермократ син Хермонов (стр. 11)

Уз то, посесивни придеви, односно, (српско)хрватски еквиваленти, који су формирани суфиксом - ски, бележе ,припадање појма уз чије име стоји, тачно одређеном, индивидуализованом појму“ (Станојчић-Поповић 19996: 153):

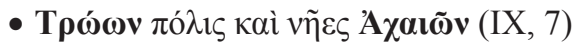

$>\quad$ иројански град и ахејске лађе (стр. 18)

\subsection{2. Субјекатски генитив: $\mathbf{N}+\mathbf{A g} /$ PseudoAg $\left[\leftarrow \mathbf{N}_{\text {Gen }}{ }^{15}\right.$}

Реч је о девербативном атрибуту који „детерминише (глаголску) именицу, а алтернира са номинативом који улази у конгруентну везу са одговарајућим глаголом“. (Фелешко 1995²: 25).

Углавном, формира се од глагола несвршеног вида, са семантичког аспекта указује на агенса или псеудоагенса, а има нијансу уопштавајуће неизвесности.

Као преводни еквиваленти субјекатском генитиву појављују се (српско) хрватски субјекатски генитив и предложне конструкције (за + акузатив; $у+$ локатив):

(а) субјекатски генитив

Узевши у обзир да се у индоевропским језицима глаголске именице шире са конгруентним атрибутима, постаје јасно како се субјекатски генитив у (српско) хрватском односи на исти грчки еквивалент:

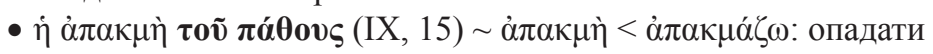

$>\quad$ опадање $\bar{u} a \bar{u} о c a$ (стр. 20)

(б) за + акузатив

Употреба предлога за уз акузатив, иако се јавља без специфичног значења (Мразовић-Вукадиновић 1990: 345), утврђује (псеудо)агенс описане радње:

15 Ag: Аїенс; PseudoAg: Псеуgоаїенс (Пипер и др. 2005: 127) 


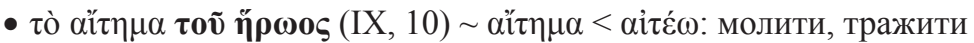

$>\quad$ молитва за јеgної јунака (стр. 19)

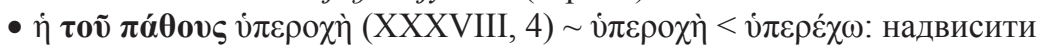

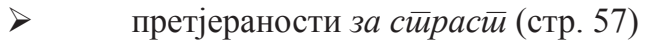

(в) $\mathbf{y}+$ локатив

Локативним конструкцијама означава се место вршења делатности која је у старогрчком оригиналу представљена са субјекатским генитивом:

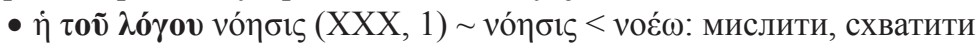

$>\quad$ мисао y їовору (стр. 46)

\subsection{3. Узрочни (Каузални) генитив: $\mathbf{N}+\operatorname{Det}_{\text {Caus }}\left[\leftarrow \mathbf{N}_{\text {Gen }}\right]$}

Природне околности које каталитички утичу на спонтану телесну или психичку реакцију ентитета уобличавају се каузалним детерминатором. На тај начин представљају се унутрашњи и спољашњи узроци, директни и индиректни (Пипер и др. 2005: 166-167).

У грчким примерима дотична врста адвербијалног генитива изражава се предлошким генитивом вредности - цене (предлог збої):

(а) генитив вредности или цене

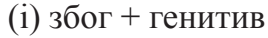

У савременом (српско)хрватском предлошка конструкција збоі $+\bar{\imath} е н и \bar{u} и в$ заузима главну позицију узрочне адвербијалне одредбе. У суштини илуструје појам који функционише као посредан (пасивни) чинилац изазивања психичких реакција:

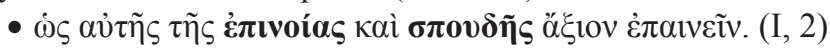

$>\quad$ колико да га хвалимо збой намјере и уложена йрyga (стр. 5)

\section{4. Закључна разматрања}

Служећи се старогрчким текстом и (српско)хрватским преводом овим радом тежимо ка проучавању семантичким параметрима и синтаксичким релацијама адноминалних генитивних конструкција.

При избору примера за грчки генитив поклонили смо посебну пажњу облицима који се појављују најчешће у оригиналном корпусу, али и тим формама које граматичарима изазивају највеће интересовање.

На основу спроведене анализе наилазимо на изненађујућу подударност, али и изразите разлике између генитивних конструкција. Конкретније:

(a) подударну употребу показују:

(1) квалитативни генитив:

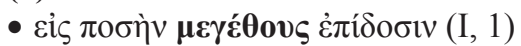

$>\quad$ на неку вишу разину стилла (стр. 5)

(2) поредбени генитив (између + генитив, међу + инструментал, од + генитив):

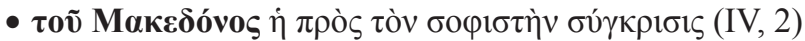

$>\quad$ та успоредба између Макеgонаиа и софиста (стр. 10) 


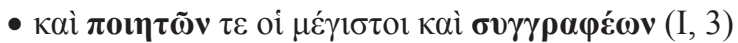

$>\quad$ те да су највећи међу ијјесницима и ирозаистиима (стр. 6)

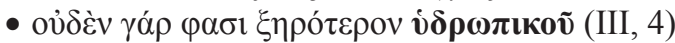

$>\quad$ ништа није непријатније og човјека који болује оg воgене болесии (стр. 9)

(3) објекатски генитив:

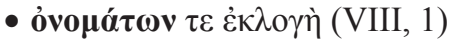

$>\quad$ избор ријечи (стр. 14) избор < изабрати

(4) присвојни генитив:

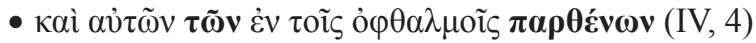

$>\quad$ очи самих gјевица (стр. 11)

(5) субјекатски генитив ( 3 a + акузатив,, + локатив):

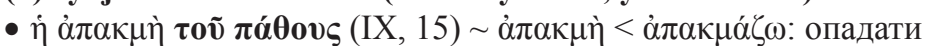

$>\quad$ опадање $\bar{u} a \bar{u} о c a$ (стр. 20)

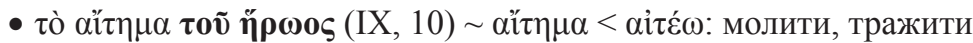

$>\quad$ молитва за јеgної јунака (стр. 19)

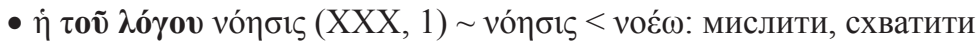

$>\quad$ мисао у іовору (стр. 46)

(б) диференцирану употребу означавају:

(1) аблативни генитив у (српско)хрватском замењује у старогрчком:

(i) квантитативни генитив:

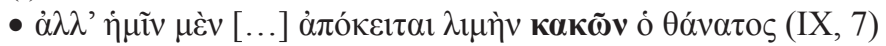

$>\quad$ смрт као лука која нас спасава og зала (стр. 18)

(ii) партитивни генитив:

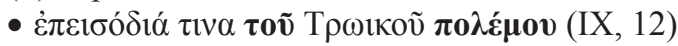

$>\quad$ неке епизоде из тројанскога райа (стр. 19)

(iii) поредбени генитив:

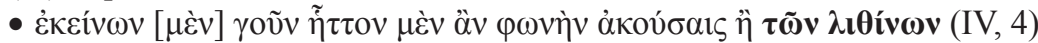

$>\quad$ прије би могао чути коју ријеч од мраморних кипова неголи og ғих (стр. 11)

(2) квалитативни генитив у преводу јавља се као преводни еквивалент:

(i) објекатском генитиву:

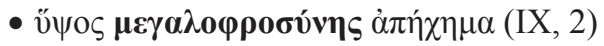

$>\quad$ узвишено је одјек великоїа gуха (стр. 16) одјек < одјековати

(ii) партитивном генитиву:

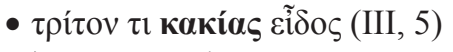

$>\quad$ трећи вид искварена стила (стр. 9)

(3) квалитативни инструментал изражава функцију:

(i) објекатског генитива:

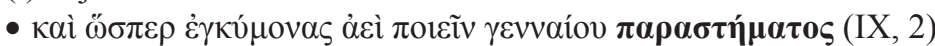

$>\quad$ да буду испуњене племенитим осјећањима (стр. 16)

(4) објекатски генитив указује на:

(i) вредност или цену:

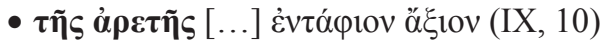

$>\quad$ погреб достојан храбростии (стр. 19)

(ii) узрок:

- $\mu \varepsilon \gamma \varepsilon \dot{\theta} \theta 0 v \varsigma$ aĩía $(\mathrm{V}, 1)$ 
$>\quad$ извор узвишеної (стр. 14) избор < изабрати

(5) описни придеви презентирају исту синтаксичку улогу са старогрчким:

(i) квантитативним генитивом:

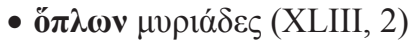

$>\quad$ безбројно оружје (стр. 63)

(ii) објекатским генитивом:

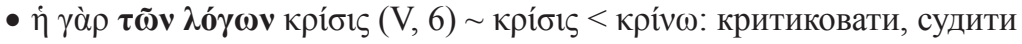
књижевна критика (стр. 13)

(6) партитивни генитив односи се на:

(i) квантитативни генитив:

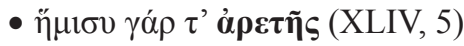
половину узме врлине (стр. 65)

(7) присвојна заменица је структура истовредна са:

(i) присвојним генитивом:

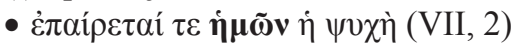

$>\quad$ наша се душа уздиже (стр. 13)

(8) присвојни генитив има троструку еквивалентну функцију, пошто заузима место:

(i) генитива ствараоца:

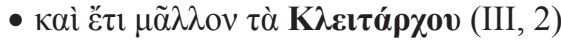

> још више изражаји лошег писца Клийарха (стр. 8)

(ii) објекатског генитива:

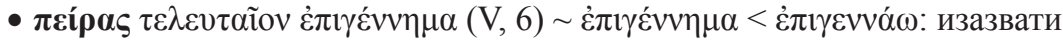

$>\quad$ плод дугог искусиива (стр. 13)

(iii) предлошке структуре ,у + генитив“:

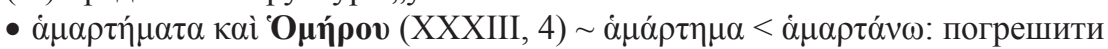

$>\quad$ недостатака у Хомера (стр. 51)

(9) присвојни датив исказује се старогрчким:

(i) субјекатским генитивом:

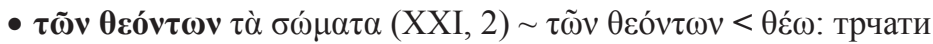

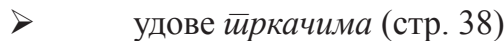

(10) присвојном придеву у (српско)хрватском преводу одговарају:

(i) генитив ствараоца:

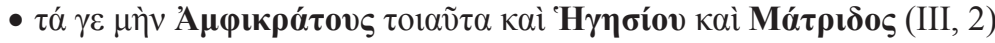

$>\quad$ такав је Амфикрайов, Хеїесијев и Майрияов стил (стр. 8)

(ii) присвојни (посесивни) генитив:

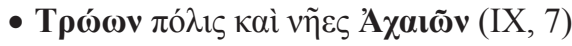

$>\quad$ иројански град и ахејске лађе (стр. 18)

(11) узрочни (каузални) генитив одређује се као еквивалент:

(i) генитиву вредности или цене (због + генитив)

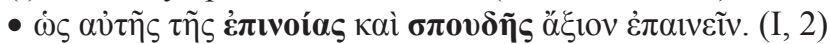

$>\quad$ колико да га хвалимо збой намјере и уложена йрyga (стр. 5)

Имајући у виду, да „разлике се указују као ограничења сличности, и обрнуто, сличности се сагледавају као ограничења разлика“ (Бугарски 1996: 399) резултати 
овог комплексног, прагмалингвистичког и међукултуралног рада могу побудити велико интересовање у домаћим или међународним лингвистичким круговима, и употребити се у лаком превођењу текстова са једног језика на други.

Паралелно на пољу испитивања међујезичке прагматичке компетенције, добијени резултати могу представљати корисно градиво за конструктивно употпуњавање и развијање наставних средстава, али и језичких стратегија у области наставе старогрчког језика.

\section{Литература}

Бугарски, Р. (1996). Језичке разлике. Српски језик, 1 (1-2): 399 - 403.

Ивић, М. (1954). Значењ а срӣскохрвайскої инсиируменйала и њихов развој. Београд: САНУ.

Ивић, М. (1955-1956). Однос изнеђу квалитативног генитива и квалитативног инструментала. Наш језик, 7 (7-10): 260-269.

Ивић, М. (1959). Српскохрватски падежни облици обавезно праћени одредбом као помоћним морфолошким знаком. Годишъак Филозофскої факулитейа у Новом Саgу, 6: 159-162.

Мразовић, П. и Вукадиновић, 3. (1990). Грамайика срӣскохрвайскої језика за стирание. Сремски Карловци: Издавачка Књижарница Зорана Стојановића, Нови Сад: Добра Вест.

Пипер, П. и др. (2005). Синйакса Савременої Срйскої језика - Просӣа реченииа. Београд: Институт за Српски језик САНУ.

Сабалевски, С. (2000). Древнеїреческий язык. Учебник gля вузов. Санкт - Петербург: Алетейя.

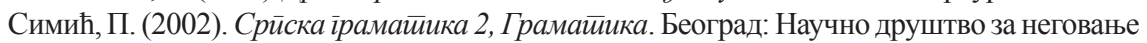
и проучавање српског језика. Никшић: ЈАСЕН.

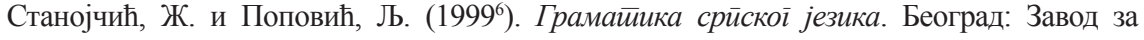
уџбенике и наставна средства.

Фелешко, К. $\left(1995^{2}\right)$. Значењ а и синйакса срӣскохрвайскої іенийива. Београд: Орфелин Adams, C. (1919). Aeschines. Cambridge: Harvard University Press.

- О лажном йослансииву (ЛП)

Burnet, J. (1900-1907). Platonis opera, I-V. Oxford: Clarendon Press.

- Горіија (Plat. Gorg.)

- Оgбрана Сократ̄ова (Plat. Apol.)

- Рейублика (Plat. Rep.)

- Симйозиј (Plat. Sym.)

Butcher, S. and Rennie, W. (1903-1931). Demosthenis Orationes, I-III. Oxford: Clarendon Press.

- Наяі̄робни їовор (Dem. 60.)

- Пройив Тимокрайа (Dem. 24.)

Dukat, Z. (1983). Gramatika Grčkoga Jezika. Zagreb: Školska knjiga.

Godley, A. D. (1920). The Histories of Herodotus, I-IV. Cambridge: Harvard University Press. - Прийовестии (Hdt.)

Jones, H. and Powell, J. (1942²). Thucydidis Historiae, I-II. Oxford: Clarendon Press.

- Истиорија Пелойонескої райа (Тhuс.)

Lamb, W. (1930). Lysias. Cambridge: Harvard University Press.

- Наяіробни іовор (Lys. 2.)

- Пройив Аїopaӣa (Lys. 13.)

- Проииив Алкибијаgа (Lys. 14.)

Marchant, E. (1900-1921). Xenophontis opera omnia, I-V. Oxford: Clarendon Press.

- Анабаза (Xen. Anab.)

- Сећања на Сокрайа (Xen. Mem.) 
- Хеленика (Xen. Hell.)

Maretić, T. $\left(1963^{3}\right)$. Gramatika hrvatskoga ili srpskoga književnog jezika. Zagreb: Matica hrvatska.

Musić, A. i Majnarić, N. $\left(1980^{11}\right)$. Gramatika Grčkoga Jezika. Zagreb: Školska knjiga.

Norlin, G. (1980). Isocrates, I-III. Cambridge: Harvard University Press.

- Кийрани (Isoc. 3.)

- Никоклу (Isoc. 2.)

- $О$ миру (Isoc. 8.)

- Панеїирик (Isoc. 4.)

Pearson, A. C. (1967). Sophoclis Fabulae. Oxford: Clarendon Press.

- Анйиїона (Soph. Ant.)

Smerdel, T. (1980). Pseudo-Longin, O uzvišenom. Zagreb: GZH.

Smyth, H. (1920). A Greek Grammar for colleges. New York: American Book Company.

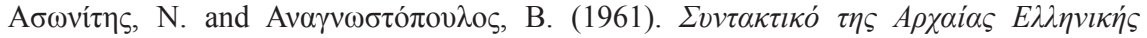

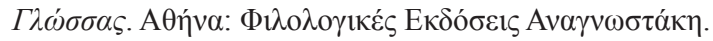

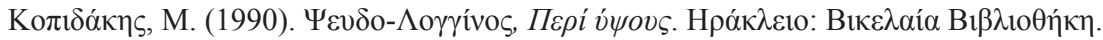

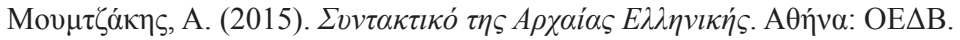

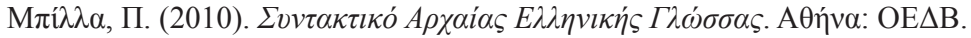

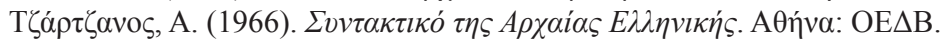

\section{Panagiotis Asimopoulos}

\section{THE ANCIENT GREEK GENITIVE AND ITS SERBO-CROATIAN TRANSLATING EQUIVALENTS IN PSEUDO-LONGINUS' ESSAY «ON THE SUBLIME»}

Summary: In this paper we contrast genitive syntagms without prepositions in two different languages, Serbian and ancient Greek. The analysis, following theoretical examination of the phenomenon, is based on 463 examples from Pesudo-Longinus' essay "On the sublime" and their Serbo-Croatian translation equivalents based on Tom Smerdel's translation.

Key words: Pseudo-Longinus, Genitive, ancient Greek, Serbo-Croatian 